\title{
PROPAGAÇÃO DE PULSOS EM MEIOS ANISOTRÓPICOS
}

\author{
Rubenvaldo Monteiro Pereira \\ Orientador: Dr. João dos Santos Protázio (UFPA) \\ 66 p. - Dissertação (Mestrado) - Defesa 11.04.2004
}

\begin{abstract}
RESUMO. Extrair informações litológicas da subsuperfície através de levantamentos de dados sísmicos tem se tornado um desafio cada vez maior à prospecção sísmica, pois a hipótese de estratificações formadas por camadas isotrópicas tem se mostrado insuficiente para representar o comportamento do campo elástico em levantamentos com grandes afastamentos entre fonte e receptor, os dados de geofones multicomponentes e as medidas de Perfil Sísmico Vertical (PSV) tridimensional, dentre outras. Devido a isto, passou-se a exigir um modelo de subsuperfície que se adequasse mais a esta nova realidade. É sob este panorama que a prospecção sísmica passa a considerar a presença de anisotropia, pois o modelo anisotrópico de subsuperfície é o que mais se aproxima dos levantamentos supra citados. Em especial, para a prospecção sísmica voltada à caracterização de reservatórios, a anisotropia induzida por fraturas é a que mais se assemelha às necessidades e está amplamente referenciada na literatura. 0 objetivo deste trabalho é apresentar um formalismo que modele o espalhamento de pulsos a partir de ondas planas incidentes em interfaces planas horizontais que separam camadas anisotrópicas. Este espalhamento é obtido através da formulação explicita dos campos de deformação e tração como função das matrizes propagadoras, de polarização e impedância do meio, formalismo posteriormente usado para a obtenção das matrizes dos coeficientes de reflexão e transmissão através de uma interface plana horizontal, que, por fim, é generalizado para o espalhamento através de múltiplas camadas. Feito isto, ao campo de onda incidente insere-se as amplitudes de um pulso analítico para finalmente se calcular 0 espalhamento do pulso através de estratificações. Para aferir a técnica apresentada são feitos experimentos numéricos utilizando-se um modelo anisotrópico intercalado por semi-espaços isotrópicos visando à análise dos efeitos da anisotropia na deformação do pulso em função da variação dos ângulos de incidência e azimutal. São também estudados os efeitos da presença de mergulhos no sistema de referência. Os resultados são apresentados na forma de sismogramas sintéticos de ondas planas refletidas, considerando-se apenas ondas incidentes $P$ pelo fato deste tipo de evento ser à base da maioria dos levantamentos comerciais. Entretanto, o formalismo é robusto o suficiente para se estudar o espalhamento de todos os eventos de ondas refletidas e transmitidas.
\end{abstract}

ABSTRACT. To extract lithological information from subsurface by means of a survey of seismic data has become a great challenging in relation to a seismic research because of the lack of insufficient hypotheses of stratification made by isotropic layers, which should represent through surveys the behavior of elastic field with great offset between source and receiver, geophones multicomponent data, measures of three-dimensional vertical seismic profile (VSP) and so forth. For this reason, a pattern of subsurface has been demanded in order to be adequated to this new reality. As a result, the seismic prospecting starts considering the presence of anisotropy, so the anisotropic pattern of subsurface is the one which is closer in of supra named surveys. In special, for the seismic survey in relation to the reservoirs characterization, the anisotropy that is induced by fractures is the one that is more similar to the needs and it is widely referred in the literature. This paper aims at showing formalism to modeling the scattered of pulses from incident plane waves occurred in horizontal plain interface which separates anisotropic layers. This scatter is obtained through clear formulation of traction deformation fields as function of propagator, polarization and impedance matrixes of media, this formalism will be later used to obtain the of transmission and reflection coefficients matrixes through a horizontal plain interface and, finally, it is generalized to a scattering through multiple layers. Doing that, it is possible to calculate the pulse scattering through layers after we insert the amplitude of analytical pulse to an incident wavefield. To check the presented technique, numerical experiments are done utilize an anisotropic model which is intercalated to isotropic semi-spaces to analyze the effects on pulses shape with the variation of the azimuthal and incidence angle as well as the presence of dipping in the reference system. The results are presented in shape to the synthetic seismograms of plane waves reflected to incident $P$-waves in view of this event is the base of the majority commercial surveys. Notwhitstanding, the formalism is robust sufficient to study the scattering of all the events of reflected and transmitted waves. 